\title{
Adenocarcinoma of the bladder 29 years after ileocystoplasty
}

\section{$\operatorname{AUTHOR}(S)$ :}

HASEGAWA, Soichiro; OHSHIMA, Shinichi; KINUKAWA, Tsuneo; MATSUURA, Osamu; TAKEUCHI, Yoshinori; HATTORI, Ryohei; MURAKAMI, Sakae

\section{CITATION:}

HASEGAWA, Soichiro ...[et al]. Adenocarcinoma of the bladder 29 years after ileocystoplasty. 泌尿器科紀要 1989, 35(4): 671-674

ISSUE DATE:

1989-04

URL:

http://hdl.handle.net/2433/116494

RIGHT: 


\title{
ADENOCARCINOMA OF THE BLADDER 29 YEARS AFTER ILEOCYSTOPLASTY
}

\author{
Soichiro Hasegawa, Shinichi Ohshima, Tsuneo Kinukawa, \\ Osamu Matsuura, Yoshinori Takeuahi and Ryohei Hattori \\ From the Department of Urology, Shakai Hoken Chukyo Hospital \\ Sakae Murakami \\ From the Department of Clinical Pathology, Shakai Hoken Chukyo Hospital
}

\begin{abstract}
We report a case of adenocarcinoma found at the bladder site 29 years after ileocystoplasty. The patient was a 43-year-old woman who had undergone a closed-loop type of ileocystoplasty for a small tuberculous contracted bladder when she was 13 years old. The tumor that arose in the bladder site was colonic type adenocarcinoma. Four cases of neoplasm occurring in the ileal portion following ileocystoplasty have been reported in the English and Japanese literature, but no case arising originally in the bladder site has been reported.
\end{abstract}

Key words: Ileocystoplasty, Adenocarcinoma of the bladder, Shelle's operation, Small contracted bladder

\section{INTRODUCTION}

In 1899 Von Mikulicz performed the first ileocystoplasty on a man for a small contracted bladder. Twenty-four years later, Shelle reported his closed type of ileocystoplasty. Since then, similar types of ileocytoplasty have been widely performed. Malignant change occurring as a late complication of ileocystoplasty was first reported by Patric Smith ${ }^{2)}$ et al. in 1971. Such cases, however, are rare in the literature and only four cases have been reported to date. We present here a fifth case in which adenocarcinoma occurred in the contracted bladder site following ileocystoplasty.

\section{CASE REPORT}

A 43-year-old woman with renal failure was placed on hemodialysis on August 26, 1985. At the age of 13, she had undergone a closed-loop type of ileocystoplasty for a small tuberculous contracted bladder. At that time, her left kidney was contracted and nonfunctioning.

On October 1, 1985, right hydronephrosis was noticed by computed tomography, and the patient was admitted to our hos- pital a week later. After percutaneous nephrostomy was performed, right renal function improved markedly and resulted in the weaning of hemodialysis. Antegrade pyelography demonstrated complete obstruction of the right lower ureter (Fig. 1). Cystography showed contracted bladder and portion of the ileal ring (Fig. 2). Cystoscopy revealed a nonpapillary tumor arising from most areas of the contracted bladder. The site of the ileal ring was not seen. Biopsy of the tumor proved moderately differentiated adenocarcinoma. On November 19, 1985, total cystectomy, urinary diversion (ureterocutaneostomy) and total hysterectomy with bilateral adnexectomy were performed. Neither an urachal remnant connected with the neoplasm nor a suprapubic neoplastic mass was seen at operation. The patient died of local recurrence 22 months postoperatively.

\section{PATHOLOGY}

A surgically resected tumor mass was located in the contracted bladder. No tumor was seen in the site of the ileal ring (Fig. 3). Microscopically, cancer cells were seen infiltrating to the subserosal tissue of the bladder wall and 


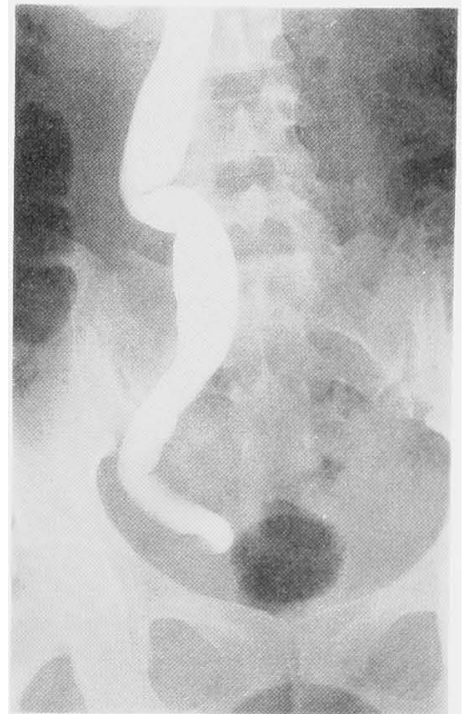

Fig. 1. Antegrade pyelography demonstrated complete obstruction of the right lower ureter.

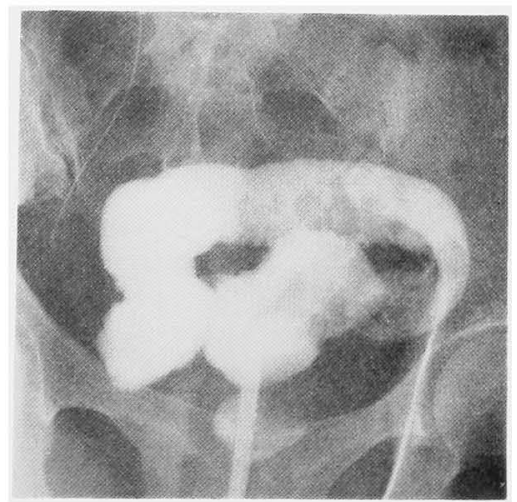

Fig. 2. Cystography showed contracted bladder and closed-loop of the ileum.

no malignant cells were recognized in the site of the ileal ring. Most parts of the epithelium between the ileal ring and the contracted bladder had disappeared and the resulting defect had become ulcerous. The other parts of the epithelium were noncarcinomatous intestinal epithelium.

Tumor cells formed glands that were lined by a high columnar cell epithelium (Fig. 4). The surface of these high columnar cells was covered by a structure similar to the brush border (Fig. 5). The cells, with eosinophilic cytoplasm, showed morphological characteristics similar to

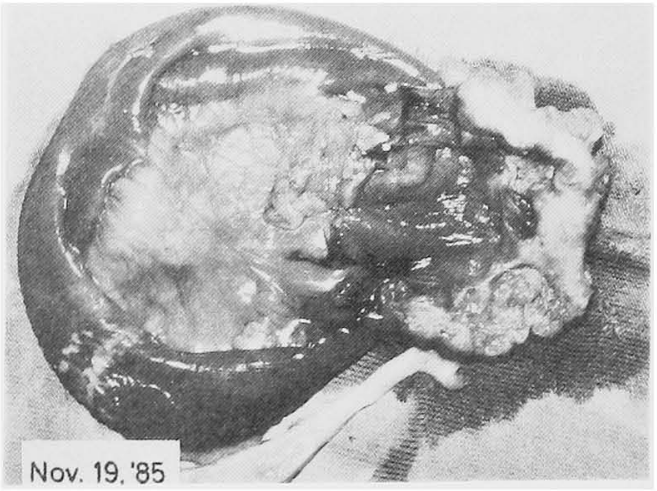

Fig. 3. This photograph shows the resected contracted bladder, right lower ureter, and closed-loop of the ileum. Nonpapillary tumor arose from most parts of the contracted bladder.

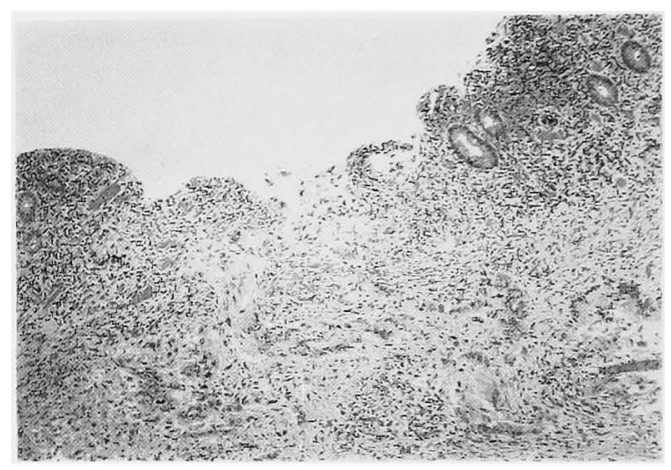

Fig. 4. This photomicrograph shows carcinoma admixed with intestinal epithlelium in the mucosa of the contracted bladder. The cancer cells seem to invade from the surface to the muscular layer.

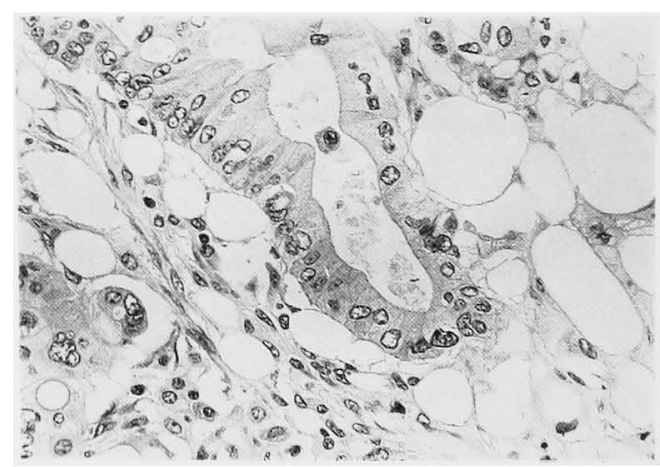

Fig. 5. This photomicrograph shows the glands of the carcinoma in the subserosa. The glands are lined by high columnar cells with eosinophilic cytoplasm. The columnar epithelia have a border that exhibits vertical striations. 
Table 1. Cases of bladder tumors following ileocytoplasty

\begin{tabular}{|c|c|c|c|c|c|c|}
\hline Author & $\begin{array}{l}\text { Patient } \\
\text { age(years) }\end{array}$ & Sex & $\begin{array}{l}\text { Original } \\
\text { condition }\end{array}$ & $\begin{array}{l}\text { Postoperative } \\
\text { years }\end{array}$ & $\begin{array}{l}\text { Pathological } \\
\text { diagnosis }\end{array}$ & $\begin{array}{l}\text { Original } \\
\text { site }\end{array}$ \\
\hline $\begin{array}{l}\text { Patrick Smith } \\
\text { (1971) }\end{array}$ & 43 & female & tuberculosis & 21 & $\begin{array}{l}\text { poorly differentiated } \\
\text { transitional cell } \\
\text { carcinoma }\end{array}$ & ileal site \\
\hline $\begin{array}{l}\text { Barbara M.Egbert } \\
\quad(1980)\end{array}$ & 43 & male & quadriplegia & 19 & $\begin{array}{l}\text { undifferentiated } \\
\text { sarcoma }\end{array}$ & ileal site \\
\hline $\begin{array}{l}\text { Etsuji Takasaki } \\
\text { (1983) }\end{array}$ & 42 & male & tuberculosis & 20 & $\begin{array}{l}\text { signet ring } \\
\text { cell adenocarcinoma }\end{array}$ & ileal site \\
\hline $\begin{array}{l}\text { Sadao Kamidono } \\
\text { (1985) }\end{array}$ & 47 & male & tuberculosis & 20 & $\begin{array}{l}\text { undifferentiated } \\
\text { adenocarcinoma }\end{array}$ & ileal site \\
\hline $\begin{array}{c}{ }^{6)} \\
\text { Present case } \\
\quad(1985)\end{array}$ & 43 & female & tuberculosis & 29 & $\begin{array}{l}\text { moderately } \\
\text { differentiated } \\
\text { adenocarcinoma }\end{array}$ & bladder site \\
\hline
\end{tabular}

the colonic cancer cells.

Cancer cells also seen in the lowest site of the right ureter, suggested complete obstruction of the right ureter closely associated with direct invasion by the bladder tumor. A metastatic lesion was also found in the right ovary. No urachal neoplastic mass was seen during the investigation.

\section{DISCUSSION}

After reviewing more than thirty cases of carcinoma of the colon after ureterosigmoidostomy, Leadbetter et al. ${ }^{1}$ commented that the incidence of colon carcinoma associated with ureterosigmoidostomy was 500 times greater than that in the normal population. On the other hand, to the best of our knowledge, only four such cases as bladder tumor occurring after ileocystoplasty were reported in the past (Table 1). The average patient age in these cases was 43.6 years. In four of the now five cases, which include the present case, the original disease was tuburculous contracted bladder. The time it took for lesions to develop varied from 19 to 21 years. In the present case $^{6)}$, cancer occurred in parts of the bladder 29 years after the primary operation. The histological diagnoses of the above five cases were as follows : three were adenocarcinoma, one was transitional cell carcinoma, and one was undifferentiated sarcoma. The present case is a rare case of bladder tumor occurring after ileocystoplasty and, in spite of careful investigation, we could find no other report of a tumor originally arising in the bladder site.

\section{REFERENCES}

1) Leadbetter GW Jr, Zickerman P and Pierce $\mathrm{E}$ : Ureterosigmoidostomy and carcinoma of the colon. J Urol 121: 732, 1979

2) Smith $P$ and Hardy GJ Carcinoma occurring as a late complication of ileocystoplasty. Br J Urol 43: 576, 1971

3) Barbara ME Jr, Kersten $\mathbf{K}$ and Inder $\mathbf{P}$ : Undifferentiated sarcoma arising in an augmented ileocystoplasty patch. J Urol 123 : 272-274, 1980

4) Takasaki E, Murahashi I, Toyoda M, Honda $\mathrm{M}$ and Waku $\mathrm{S}$ : Signet ring cell adenocarcinoma of ileal segment following ileocystoplasty. J Urol 130: 562-563, 1983

5) Kamidono $S$, Arakawa $S$, Umezu $K$ and Ishigami $G$ : A rare case of adenocarcinoma of bladder following augmentation enterocystoplasty. Acta Urol Jpn 31: 315-318, 1985

6) Hasegawa S, Ohshime S, Kinukawa T, Matsuura $\mathrm{O}$, Takeuchi $\mathrm{Y}$, Hattori $\mathrm{R}$ and $\mathrm{Mu}-$ rakami $S$ : Adenocarcinoma of the bladder 29 years after ileocystoplasty. Br J Urol 61: 162,1988

(Accepted for publication March 27, 1988) 


\section{和文抄録}

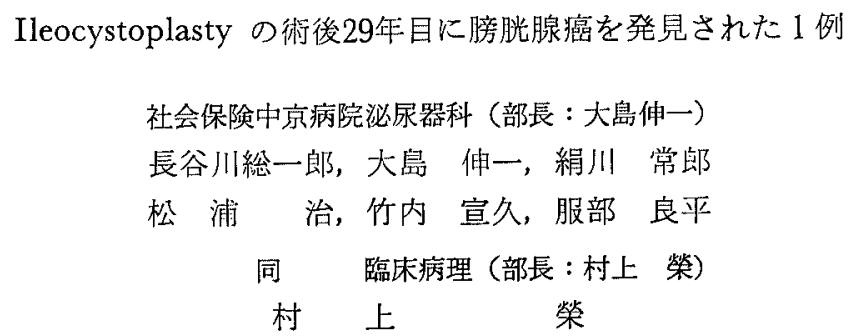

Ileocystoplasty の術後 29 年目に，膀胱部の腺癌を 発見された1例を報告する.症例は43歳女性で，13歳 の時に, 結核性萎縮膀胱に対し, 回腸環を用いた ileocystoplasty を施行されている. 䧛胱部に発生した 腫癔は，腸管型の腺癌であった. ileocystoplasty の
術後, 回腸部に腫瘍の発生をみた症例は, 和文および 英文の文献をみる限り，4例の報告例があるが，膀胱 部に腫瘍の発生をみた症例は，過去に見当たらなか った.

（泌尿紀要 $35 ： 671-674 ， 1989 ）$ 